\title{
Silage production and the chemical composition of corn and Grass- tanzania intercropping
}

\author{
Produção e composição química da silagem de milho e capim- \\ Tanzânia em consórcio
}

\author{
Fabiana Luiza Matielo de Paula ${ }^{1 *}$; Luis Fernando Glasenapp de Menezes ${ }^{2}$; \\ Wagner Paris ${ }^{2}$; Ricardo Ronsani ${ }^{3}$; Sarah Maria Hoppen ${ }^{4}$; Julio Ciesca ${ }^{5}$
}

\begin{abstract}
The objective of this study was to evaluate the production and chemical composition of silages of grass Tanzania and corn, grown single or intercropping. The experiment was conducted at UTFPR Câmpus Dois Vizinhos in the period between October 2011 and July 2012, a $600 \mathrm{~m}^{2}$ area. The treatments were: TMI - single corn, TMT - corn and grass Tanzania consortium at the time of sowing, TT - Tanzania grass single, TT32 - grass Tanzania silage to $32 \%$ dry matter (content similar to that of corn). The experimental design a randomized block design with four treatments and five replications. Agronomic evaluations were performed 120 days after planting, as follows: number of linear-1 plants metro, plant height and ear insertion and number of ears.plants ${ }^{-1}$. In the grass we evaluated canopy height, where it was held the botanical separation in green leaves, dried and stem. Silage started being held in 100 $\mathrm{mm}$ PVC pipe (mini-silos) kept sealed for 60 days. At the time of opening of the silo were determined the following parameters: DM, $\mathrm{pH}$, total loss of DM (PDM), specifies mass (SM), dry matter recovery indices (IRDM), losses gas (LG), and size particle. Chemical analysis of the results of OM, MM, ADF were higher for TMI treatments, TT and TT, respectively. CP and LIG had superior results for the treatments containing grass. Corn intercropping with grass Tanzania silage provides more crude protein and lignin compared to exclusive corn silage without damaging the crop yield. Silage maiden Tanzania has higher levels of ADF and crude protein as well as increased production of dry matter than corn silage. The grass Tanzania should be harvested with $30 \% \mathrm{DM}$ as presented better $\mathrm{pH}$ values, higher dry matter recovery rate, less loss of gas as well as increased production of dry matter that Tanzania harvested at the same age corn.
\end{abstract}

Key words: Analysis bromatological. Forage conservation. Intercropping. Microsilos.

\section{Resumo}

Objetivou-se avaliar a produção e composição bromatológica de silagens de capim Tanzânia e de milho, cultivados solteiros ou consorciados. O experimento foi conduzido na UTFPR Câmpus Dois Vizinhos no período entre outubro de 2011 e julho de 2012, numa área de $600 \mathrm{~m}^{2}$. Os tratamentos utilizados foram: TMI - milho solteiro, TMT - milho e capim- Tanzânia consorciados no momento da semeadura, TT - capim-Tanzânia solteiro, TT32 - capim-Tanzânia ensilado a 32\% de matéria seca (teor semelhante

\footnotetext{
${ }^{1}$ Pós-Doutoranda em Zootecnia, Universidade Tecnológica Federal do Paraná, UTFPR, Dois Vizinhos, PR, Brasil. E-mail: fabianadepaula3@hotmail.com

2 Profs., Drs., UTFPR, Dois Vizinhos, PR, Brasil. E-mail: luismenezes@utfpr.edu.br; wagner@utfpr.edu.br

${ }_{3}$ Mestre em Zootecnia, UTFPR, Dois Vizinhos, PR, Brasil. E-mail: ricardoronsani@hotmail.com

${ }^{4}$ Discente de Mestrado em Zootecnia, Universidade Estadual do Oeste Paraná, UNOESTE, Marechal Cândido Rondon, PR, Brasil.

E-mail: sarah.hoppen@hotmail.com

${ }^{5}$ Discente de Graduação em Zootecnia, UTFPR, Dois Vizinhos, PR, Brasil. E-mail: juliociesca@hotmail.com

* Author for correspondence
} 
ao do milho). O delineamento experimental foi em blocos ao acaso, com quatro tratamentos e cinco repetições. As avaliações agronômicas foram realizadas 120 dias após a semeadura, sendo elas: número de plantas metro linear ${ }^{-1}$, altura da planta e inserção de espiga e número de espigas planta ${ }^{-1}$. No capim avaliou-se altura do dossel, onde foi realizada a separação botânica em folhas verdes, secas e colmo. A ensilagem foi realizada em tubos de PVC de $100 \mathrm{~mm}$ (microsilos), mantidos vedados por 60 dias. No momento da abertura do silo foram determinados os seguintes parâmetros: MS, $\mathrm{pH}$, perda total de MS (PMS), massa específica (ME), índice de recuperação de massa seca (IRMS), perdas de gases (PG),e tamanho de partícula. Das análises bromatológicas os resultados de MO, MM, FDA foram superiores para os tratamentos TMI, TT e TT, respectivamente. PB e LIG tiveram resultados superiores para os tratamentos contendo capim. O consórcio de milho com Capim Tanzânia proporciona silagem com maior teor de proteína bruta e lignina em comparação com a silagem exclusiva de milho, sem prejudicar a produtividade da cultura. A silagem de Tanzânia solteira apresenta maiores teores de FDA e de proteína bruta, além de maior produção de matéria seca que a silagem de milho. O capim Tanzânia deve ser colhido com 30\% de MS visto que apresentou melhores valores de $\mathrm{pH}$, maior índice de recuperação de MS, menor perda de gases, além de maior produção de matéria seca, do que a Tanzânia colhida com a mesma idade do milho.

Palavras-chave: Composição bromatológica. Conservação de forragem. Consorciação. Microsilos.

\section{Introduction}

One of the ways of using the grain for animal feeding is the production of silage, which is basically the partial fermentation of the plant. The main source for the silage is corn, for having between $30 \%$ and $35 \%$ dry matter (DM), more than $3 \%$ carbohydrates, low cap power and good microbial fermentation (ZEOULA et al., 2003). Corn is used in animal feeding in the form of grains or preserved (silage) in times of scarcity of pasture. In addition, influences on soil tillage, rotating crops in crop livestock integration system, eliminating pests, providing coverage for the soil in the post-harvest period, among other benefits. The constant search for alternatives for preserving food bulky to ruminants has enabled producers to diversify the productive system, allowing the same not being exclusively dependent of corn silage that despite its high production potential and qualitative features high cost for deployment, management and harvesting of corn, but still becomes a low-cost food per kilogram of dry matter by its high mass production (EMBRAPA, 2005).

Grass-Tanzania is characterized as a high productivity highly palatable grass (from 24 to 38 ton. of DM ha year-1), with great participation of leaves, which results in high nutritional value with an average dry matter digestibility (IVDMD) of $61.7 \%$. This quality is enough to be included in the diet of animals in times of food shortages in the saved form (silage). Combined planting produces multiple benefits to producers, the environment and culture due to the different practices adopted to adapt to the ground for the recovery of degraded areas, with the improvement of the physical and chemical soil conditions due to the deployment of the pastures and exploitation of residual nutrients of crops for the production of fodder for the dry season.

The replacement of corn and sorghum silages, traditionally used in animal feed, for the grass silages, has arousing the interest as a reserve during the period of shortage of pasture. Thus, silages can also be produced with grasses as raw material; when there is a good production, the surplus is used for this purpose. This process has been more used over the years and its use leads to an increase in production by area and fewer losses, when compared to corn, for example (CORRÊA et al., 2002). However the values by carbohydrates and raw material represent their negative point, being both low and negatively altering the fermentation 
process by decreasing the nutritional quality of the food, making necessary the supplementation with other sources of nutrients.

The objective was to evaluate the production and bromatological composition of grass-Tanzania and corn, grown single or intercropping.

\section{Material and Methods}

The experiment was conducted at the Núcleo de Ensino e Pesquisa de Ruminantes (NEPRU) of the Federal University of Technology of the Dois Vizinhos Paraná campus in the period between October 2011 and July 2012. The experimental station is located in the Southwest region of Paraná, at a latitude $25^{\circ} 44$ " South and longitude of $53^{\circ} 04^{\prime \prime}$ West, with an altitude of $520 \mathrm{~m}$. The climate of the region is classified as Cfa (humid subtropical) without a defined dry season, with an average temperature on the hottest month of $22^{\circ}$ $\mathrm{C}$, according to Köppen (Table 1). The local soil is of dystropherical red nitro-soil type (BHERING; SANTOS, 2008).

Table 1. Average values of air temperature (maximum and minimum), relative humidity (RH) and precipitation during the period from September 2011 to February 2012. Dois Vizinhos (PR), 2011/2012.

\begin{tabular}{|c|c|c|c|c|c|}
\hline \multirow{2}{*}{ Mês } & \multicolumn{3}{|c|}{ Temperature $\left({ }^{\circ} \mathrm{C}\right)$} & \multirow{2}{*}{$\begin{array}{l}\text { RH } \\
(\%)\end{array}$} & \multirow{2}{*}{$\begin{array}{l}\text { Precipitation } \\
\quad(\mathrm{mm})\end{array}$} \\
\hline & Minimun & Maximum & Means & & \\
\hline Ouctuber & 10,6 & 33 & 21,25 & 67,7 & 234 \\
\hline November & 12,1 & 33 & 21,63 & 67,6 & 139 \\
\hline Dezember & 11 & 35,7 & 23,4 & 63,9 & 42,6 \\
\hline January & 15,1 & 33,1 & 23,04 & 68,8 & 177,4 \\
\hline
\end{tabular}

Source: Meteorological data - Dois Vizinhos (INMET, 2011).

The experimental design used was random blocks with four treatments (TMI-single corn, TMT - intercropping corn and grass-Tanzania at the time of sowing, TT -single grass-Tanzania harvested at the same time of corn, TT32 - grass-Tanzania silage at $32 \%$ of dry matter (content similar to corn) divided into 20 plots with dimensions of $5 \times 6 \mathrm{~m}$ with an area of $30 \mathrm{~m}^{2}$, of which $6 \mathrm{~m}^{2}$ corresponds to the surround of each parcel, totaling an area of $600 \mathrm{~m}^{2}$, with five repetitions where all treatments were distributed. For the harvest of grass-Tanzania at $32 \%$ of dry matter samples were collected before the harvest and when it reached the expected value $(32 \%$ of DM) the plots were harvested. However, due to the variability of the material harvested the actual dry matter was around $30 \%$ (Table 2). 
Table 2. Bromatological composition of corn silages and Tanzania in single and intercropping crops. Dois Vizinhos (PR), 2011/2012.

\begin{tabular}{lcccccc}
\hline Variables $^{1}$ & \multicolumn{3}{c}{ Treatments $^{2}$} & \multirow{2}{*}{ Means } & \multirow{2}{*}{$\mathrm{P}>\mathrm{F}$} \\
\cline { 2 - 4 } & Crops & Crops + tanz. & Tanzania & Tanzania 32\% & & \\
\hline DM & $30,3 \pm 0,98 \mathrm{~A}$ & $26,7 \pm 1,10 \mathrm{~A}$ & $22,0 \pm 0,98 \mathrm{~B}$ & $30,4 \pm 0,98 \mathrm{~A}$ & 27,59 & 0,0014 \\
$\mathrm{MM}$ & $4,5 \pm 0,32 \mathrm{C}$ & $5,8 \pm 0,36 \mathrm{~B}$ & $10,7 \pm 0,32 \mathrm{~A}$ & $9,9 \pm 0,32 \mathrm{~A}$ & 7,68 & 0,0001 \\
OM & $95,5 \pm 0,32 \mathrm{~A}$ & $94,2 \pm 0,36 \mathrm{~B}$ & $89,7 \pm 0,32 \mathrm{C}$ & $90,1 \pm 0,32 \mathrm{C}$ & 92,32 & 0,0001 \\
$\mathrm{ADF}$ & $27,9 \pm 1,79 \mathrm{C}$ & $34,9 \pm 2,07 \mathrm{~B}$ & $45,7 \pm 1,79 \mathrm{~A}$ & $38,7 \pm 1,79 \mathrm{~B}$ & 36,87 & 0,0002 \\
$\mathrm{NDF}$ & $65,98 \pm 1,85$ & $69,29 \pm 1,85$ & $65,57 \pm 1,85$ & $61,90 \pm 1,85$ & 65,68 & 0,0949 \\
$\mathrm{CP}$ & $10,4 \pm 0,67 \mathrm{~B}$ & $11,7 \pm 0,78 \mathrm{~A}$ & $12,7 \pm 0,67 \mathrm{~A}$ & $10,9 \pm 0,67 \mathrm{~A}$ & 11,34 & 0,0261 \\
LIG & $5,4 \pm 0,65 \mathrm{~B}$ & $8,4 \pm 0,80 \mathrm{~A}$ & $9,2 \pm 0,69 \mathrm{~A}$ & $8,1 \pm 0,69 \mathrm{~A}$ & 7,73 & 0,0141 \\
$\mathrm{EE}$ & $3,5 \pm 0,46$ & $4,6 \pm 0,54$ & $3,8 \pm 0,47$ & $3,5 \pm 0,47$ & 3,78 & 0,4171 \\
ADIN & $0,07 \pm 0,02$ & $0,09 \pm 0,02$ & $0,15 \pm 0,02$ & $0,12 \pm 0,01$ & 0.11 & 0,1439 \\
\hline
\end{tabular}

$\mathrm{DM}^{1}$ : dry matter; MM: mineral matter; OM: organic matter; ADF: acid detergent fiber; NDF: neutral detergent fiber; CP: crude protein; LIG: lignin; EE: ether extract; ADIN: acid detergent insoluble nitrogen.

${ }^{2}$ different Letters in the same line indicate that the treatments differ to 5 of significance by Tukey test.

The planting was held on 10/08/2011, with a no-tillage seeder into an area of crop-livestock integration, on a swathe of black oats. In the treatments with corn, it was prescribed a $90 \mathrm{~cm}$ spacing between rows, and 6 to 7 seed density / linear meter ${ }^{-1}$ resulting in a population between 60000 to 70000 plants $^{-1} \mathrm{a}^{-1}$, with a depth of planting between 3 to $5 \mathrm{~cm}$. In the intercropping, the deployment of grass-Tanzania occurred between the lines of maize, thus obtaining two lines of grass per one of corn, the cultural value of grass was 75.3 , with purity of 90 and 80 of viable seeds. The spacing between rows was of $30 \mathrm{~cm}$, depth between 2 to $3 \mathrm{~cm}$ and sowing density of $12.8 \mathrm{~kg} \mathrm{ha}^{-1}$.

On the basic fertilizer were used $600 \mathrm{~kg} \mathrm{ha}^{-1}$ of NPK fertilizer formula $08-18-2$ and on the fertilization of coverage were used $120 \mathrm{~kg}$ of $\mathrm{N} \mathrm{ha}^{-1}$, fractioned in two applications, using urea as nitrogen source (45\%). The first application occurred at 48 days and the second 62 days after deployment.

The agronomic evaluation on corn culture was performed 120 days after planting, to wit: plant number linear meter $^{-1}$, plant height, ear insertion height and number of ear per plant ${ }^{-1}$. For botany separation five plants of each treatment were removed randomly, the variables observed were: dead and vivid leaves, ears, culm, tassel, cob and straw. In the grass canopy height was evaluated, where it was held the botanical separation, separating the green and dried leaves and culm. The samples obtained in the botanical separation were taken to an oven at $55^{\circ} \mathrm{C}$ for 72 hours, determining the dry matter of both species.

Silage began when the corn plants reached around $30 \%$ of dry matter, about $02 / 09 / 2012$, totaling a period of 124 days, for the treatments (TMI; TMT; TT). For the harvest, the harvester was adjusted to a particle size between 2 and $5 \mathrm{~cm}$ at a cutting height of $20 \mathrm{~cm}$ from the soil. For the evaluation of dry and green matter production a sample was collected equivalent to four linear meters. The silage of the chopped material was held in $100 \mathrm{~mm}$ PVC pipes (micro-silos), with a height of $50 \mathrm{~cm}$ and $10 \mathrm{~cm}$ diameter. The default compression density was 800 $\mathrm{kg} \mathrm{MV} \mathrm{m}{ }^{3}$.

The micro-silos were kept sealed for 60 days, so that the fermentation was efficient. At the time of opening the silo the following parameters were determined: dry mass (DM), $\mathrm{pH}$, total losses of dry matter (DML), specific mass (SM), dry mass recovery index (DMRI), losses gas during storage (LG), gas losses as a percentage of dry matter (G) 
and particle size (JOBIM et al., 2007).

Silage samples were pre dried in an oven at $55^{\circ}$ $\mathrm{C}$, pounded into a Willy-type mill in a two $\mathrm{mm}$ sieve and stored for subsequent completion of the bromatological analyses. The DM content was determined by drying in the oven at $105^{\circ} \mathrm{C}$ for at least 16 hours. $\mathrm{OM}$ and $\mathrm{MM}$ were determined by combustion at $600^{\circ} \mathrm{C}$ during 4 hours. Total nitrogen (N) was determined by the Kjeldahl method (AOAC, 1997) (984.13 Method). The levels of $\mathrm{CP}$ were calculated as $\mathrm{N} \times 6.25$. EE content was determined by treatment of the sample with diethyl ether in reflux system, at $60^{\circ} \mathrm{C}$ for 4 hours (Soxhlet). The concentration of ADF was analyzed according to the 973.18 Method of AOC (AOAC, 1997). The nitrogen insoluble in acid detergents (NIDA) were analyzed according to Licitra et al. (1996).

The results were submitted to analysis of variance and, when found significant difference (5\%), the averages were compared by Tukey test ( $p$ $\leq 0.05)$ using the SAS Statistical Software (2001).

\section{Results and Discussions}

The production of $\mathrm{DM}$ ha $^{-1}$ was lower $(\mathrm{P} 0<0.01)$ on treatments which included corn (TMI and TMT), single Tanzania presented intermediate values and Tanzania at $32 \%$ of DM presented the best result (Table 2). Maia et al. (2000), when comparing intercropping and single millet and grass Tanzania under different sowing densities and different cuts achieved higher DM yield result in the intercropping, demonstrating the presence of millet on high production of DM.

The difference in production of $\mathrm{DM} \mathrm{ha}^{-1}$ between single and silage grass Tanzania to at $32 \%$ of DM is highly linked to canopy height of different treatments, while the single grass presented average height of $1.23 \mathrm{~m}$, a Tanzania at $32 \%$ had an average height of $1.70 \mathrm{~m}$ (Table 3 ).

Table 3. Evaluation of corn silage production and agronomic data and grass-Tanzania in single or intercropping cultivation. Dois Vizinhos (PR), 2011/2012.

\begin{tabular}{|c|c|c|c|c|c|c|}
\hline \multirow{2}{*}{ Variables } & \multicolumn{4}{|c|}{ Treatments } & \multirow{2}{*}{ Means } & \multirow{2}{*}{$\mathrm{P}>\mathrm{F}$} \\
\hline & Corn & Corn $+\operatorname{tanz}$. & Tanzania & Tanzania $32 \%$ DM & & \\
\hline Production (Ton. MS/ha) & $12,3 \pm 2,7 \mathrm{C}$ & $11,4 \pm 3,1 \mathrm{C}$ & $22,2 \pm 2,8 \mathrm{~B}$ & $43,3 \pm 2,7 \mathrm{~A}$ & 22,82 & 0,0001 \\
\hline Green leaf (\%DM) & $17,6 \pm 3,2 \mathrm{C}$ & $21,8 \pm 3,7 \mathrm{C}$ & $60,9 \pm 3,2 \mathrm{~A}$ & $42,12 \pm 3,2 \mathrm{~B}$ & 36,1 & 0,0001 \\
\hline Dry leaf (\%DM) & $6,7 \pm 0,6 \mathrm{~B}$ & $10,5 \pm 0,7 \mathrm{~A}$ & $4,5 \pm 0,6 \mathrm{~B}$ & $4,74 \pm 0,6 \mathrm{~B}$ & 6,2 & 0,0001 \\
\hline Culm (\%DM) & $22,3 \pm 3,8 \mathrm{C}$ & $19,6 \pm 4,4 \mathrm{C}$ & $34,5 \pm 3,8 \mathrm{~B}$ & $51,7 \pm 3,8 \mathrm{~A}$ & 32,9 & 0,0001 \\
\hline Tassel (\%DM) & $1,4 \pm 0,3$ & $2,3 \pm 0,4$ & & $3,19 \pm 0,6$ & 2,1 & 0,1172 \\
\hline Grains (\%DM) & $31,6 \pm 3,8$ & $20,2 \pm 4,7$ & & & 26,4 & 0,1596 \\
\hline Straw $(\% \mathrm{DM})$ & $10,6 \pm 0,6 \mathrm{~B}$ & $14,9 \pm 0,7 \mathrm{~A}$ & & & 12,7 & 0,0191 \\
\hline Cob $(\% \mathrm{DM})$ & $10,3 \pm 0,8$ & $10,8 \pm 1,1$ & & & 10,5 & 0,7315 \\
\hline \multicolumn{7}{|l|}{ Other evaluations } \\
\hline Corn Plant height (m) & $1,6 \pm 0,02 \mathrm{~A}$ & $1,4 \pm 0,02 \mathrm{~B}$ & & & 1,5 & 0,0038 \\
\hline canopy height Tanzania (m) & & $1,5 \pm 0,05 \mathrm{~B}$ & $1,2 \pm 0,05 \mathrm{C}$ & $1,7 \pm 0,05 \mathrm{~A}$ & 1,4 & 0,0006 \\
\hline Insertion of ear height (m) & $0,9 \pm 0,02 \mathrm{~A}$ & $0,8 \pm 0,02 \mathrm{~B}$ & & & 0,9 & 0,0232 \\
\hline Plant $m$ linear ${ }^{-1}(\mathrm{n})$ & $8,3 \pm 0,25 \mathrm{~A}$ & $7,8 \pm 0,31 \mathrm{~A}$ & & & 8,1 & 0,0299 \\
\hline Plant ears (n) & $1,0 \pm 0,05 \mathrm{~A}$ & $1,1 \pm 0,05 \mathrm{~A}$ & & & 1,0 & 0,0391 \\
\hline
\end{tabular}

${ }^{1}$ Different letters on the same line indicate that the treatments differ among themselves at $5 \%$ of significance by Tukey test.

The lack of difference in the production of DM between single and mixed corn occurred by competition among species, this result is associated with superior height $(\mathrm{P} 0<0.01)$ of corn in relation to 
the mixed one. Despite these differences in the heights of the corn, dry matter production was not affected due to the presence of Tanzania that has added value in production. While in the Intercropping the corn had lower height, Tanzania presented a top height in the intercropping $(\mathrm{P} 0<0.01)$ as related to single Tanzania, thus explaining the possible competition for light. The height of insertion of spike was also influenced by the presence of the grass, and was lower in the intercropping in function of time and competition (Table 3).

Tanzania presented the highest $(\mathrm{P}<0.01)$ percentage of greens leaves (GL), while Tanzania at $32 \%$ of DM was superior only to the single corn and the intercropping, among which there were no differences. The percentage of dry leaves (DL) was higher in the corn intercropping + Tanzania $(\mathrm{P}<0.01)$ being correlated to the percentage content of straw. This behavior can be explained by the high density of plants in the intercropping, thus resulting in competition between plants and greater canopy height, preventing the infiltration of light for the remainder of the plant and favoring the senescence.
Grass-Tanzania with $32 \%$ of DM showed the highest percentage of thatched roofs $(\mathrm{P}<0.05)$, depending on the age of the plant with the late harvest, the further development of these plants had on lignification of such a structure allowing greater participation in the evaluation. This result does not favor the culture to produce silage, because this structure complicates the digestibility of food.

The grass Tanzania silage presented a higher $\mathrm{pH}$ value $(\mathrm{P}<0.01)$ when compared with the other treatments (Table 4). The highest value of $\mathrm{pH}$ observed may be related to low soluble carbohydrates content of grass, low content of nonsilage DM (22) and age of the plant, thus hampering the fermentation and quality of silage compared to other treatments. Loures et al. (2005) evaluated the chemical composition of grass -Tanzania silage under addition of Inoculants and enzymes, different sizes of particle and different levels of DM in silage wilted or not and found higher $\mathrm{pH}$ values in the silage without wilting. Ávila (2003) recommends the addition of Inoculants for more accelerated reduction of the $\mathrm{pH}$ of the grass -Tanzania silage.

Table 4. Levels of $\mathrm{pH}$, particle size (PS), not silage dry matter content (DM), specified mass silage and non-silage $(\mathrm{SM})$, total losses in dry matter (DML), dry mass recovery index (RDM), losses gas during storage (LG), gas losses in percentage of the DM (G) after the non-silage. Dois Vizinhos (PR), 2011/2012.

\begin{tabular}{|c|c|c|c|c|c|c|}
\hline \multirow{2}{*}{ Variables } & \multicolumn{4}{|c|}{ Treatments } & \multirow{2}{*}{ Means } & \multirow{2}{*}{$\mathrm{P}>\mathrm{F}$} \\
\hline & Corn & Corn+tanz. & Tanzania & Tanzania $32 \%$ & & \\
\hline $\mathrm{pH}$ & $3,5 \pm 0,10 \mathrm{~B}$ & $3,5 \pm 0,1 \mathrm{~B}$ & $4,91 \pm 0,1 \mathrm{~A}$ & $3,45 \pm 0,10 \mathrm{~B}$ & 3,86 & 0,0001 \\
\hline PS 2 mm (\%) & $1,6 \pm 0,3 \mathrm{~A}$ & $0,6 \pm 0,3 \mathrm{AB}$ & $0,23 \pm 0,3 \mathrm{~B}$ & $0,83 \pm 0,28 \mathrm{AB}$ & 0,84 & 0,0175 \\
\hline PS 4 mm (\%) & $9,5 \pm 1,4 \mathrm{AB}$ & $8,5 \pm 1,5 \mathrm{AB}$ & $6,98 \pm 1,4 \mathrm{~B}$ & $13,62 \pm 1,37 \mathrm{~A}$ & 9,72 & 0,0239 \\
\hline PS 7 mm (\%) & $35,3 \pm 3,1 \mathrm{C}$ & $42,7 \pm 3,4 \mathrm{BC}$ & $55,65 \pm 3,1 \mathrm{~A}$ & $49,59 \pm 3,07 \mathrm{AB}$ & 45,99 & 0,0020 \\
\hline PS 12 mm (\%) & $20,6 \pm 2,0 \mathrm{AB}$ & $23,7 \pm 2,3 \mathrm{~A}$ & $14,96 \pm 2,0 \mathrm{~B}$ & $15,81 \pm 2,04 \mathrm{AB}$ & 18,51 & 0,0354 \\
\hline $\mathrm{PS}>12 \mathrm{~mm}(\%)$ & $32,9 \pm 3,1 \mathrm{~A}$ & $24,4 \pm 3,5 \mathrm{AB}$ & $22,17 \pm 3,1 \mathrm{AB}$ & $18,45 \pm 3,10 \mathrm{~B}$ & 24,48 & 0,0307 \\
\hline DM non- silage (\%) & $30,3 \pm 0,9 \mathrm{~A}$ & $26,7 \pm 1,1 \mathrm{~A}$ & $22,00 \pm 0,9 \mathrm{~B}$ & $30,40 \pm 0,98 \mathrm{~A}$ & 27,37 & 0,0001 \\
\hline SM silage (kg) & $271,6 \pm 8,6 \mathrm{~A}$ & $239,4 \pm 9,7 \mathrm{AB}$ & $197,45 \pm 8,7 \mathrm{C}$ & $233,88 \pm 8,68 \mathrm{BC}$ & 235,40 & 0,0003 \\
\hline SM non-silage (kg) & $290,9 \pm 9,8 \mathrm{~A}$ & $229,2 \pm 11,0 \mathrm{~B}$ & $212,82 \pm 9,84 \mathrm{~B}$ & $233,85 \pm 9,84 \mathrm{~B}$ & 242,34 & 0,0003 \\
\hline DML (\%) & $14,7 \pm 2,9 \mathrm{AB}$ & $6,99 \pm 3,2 \mathrm{~B}$ & $18,61 \pm 2,91 \mathrm{AB}$ & $19,26 \pm 2,91 \mathrm{~A}$ & 15,31 & 0,0520 \\
\hline RMS (\%) & $85,3 \pm 2,8 \mathrm{AB}$ & $94,8 \pm 3,13 \mathrm{~A}$ & $80,97 \pm 2,80 \mathrm{~B}$ & $93,17 \pm 2,80 \mathrm{~A}$ & 88,23 & 0,0123 \\
\hline LG (\%) & $0,27 \pm 0,06 \mathrm{~B}$ & $0,42 \pm 0,06 \mathrm{AB}$ & $0,57 \pm 0,06 \mathrm{~A}$ & $0,19 \pm 0,06 \mathrm{~B}$ & 0,36 & 0,0020 \\
\hline $\mathrm{G}(\%)$ & $14,7 \pm 3,0 \mathrm{AB}$ & $7,0 \pm 3,4 \mathrm{AB}$ & $18,61 \pm 3,03 \mathrm{~A}$ & $5,81 \pm 3,03 \mathrm{~B}$ & 11,77 & 0,0291 \\
\hline
\end{tabular}

${ }^{1}$ Different letters on the same line indicate that the treatments differ among themselves at $5 \%$ of significance by Tukey test. 
On the silage of single Tanzania which showed a higher $\mathrm{pH}$ it was also showed a lower nonsilage DM content $(\mathrm{P}<0.01)$. From that, one can infer that the grass-Tanzania silage has an inferior quality when compared with the other treatments. On grass Tanzania silage with DM similar to corn (32\%), about $64 \%$ of its particles were selected to the $7 \mathrm{~mm}$ sieve. The grass Tanzania silage had greater participation in the particle size in a $7 \mathrm{~mm}$ sieve $(\mathrm{P}<0.05)$, and the corn the less participation with a value of $35.3 \%$. In a $2 \mathrm{~mm}$ sieve, the maize presented a percentage $(1.66 \%)$ differed $(\mathrm{P}<0.05)$ of young Tanzania $(0.23 \%)$. In the selection at 4 $\mathrm{mm}$ there was a difference only between Tanzania at $32 \%$ and single with $13.65 \%$ and $6.98 \%$ values, respectively.

The Intercropping showed the highest percentage of particles with $12 \mathrm{~mm}(\mathrm{P}<0.05)$ while in single Tanzania a lower percentage; on a sieve over 12 $\mathrm{mm}$ the percentage of corn was higher (32.91\%) while Tanzania $32 \%$ of DM presented the smallest percentage when compared to other treatments $(\mathrm{P}<0.05)$.

The particle size, according to Loures et al. (2005) before the decision-making on the particle size, since the higher the content of DM the smaller the particle size, the smaller shall be the loss by effluent. There is also the difference in particle size obtained in different types of silo. Neumann et al. (2005) evaluated the inaccuracy of the silage compression obtained in laboratory silos when compared to trench and surface type silos, however the ease of control, speed, greater use of physical space and possibility of comparison of different treatments lead to use of silo made of PVC pipes.

The specific mass (SM) is determined by the dimension of the plant and becomes the determining factor in the quality of the food. It is highly correlated to the particle size and content of DM, because porosity resulting from compression of the silo, associated with the amount of water may or may not extend the breathing of bacteria in sealed silo, with higher consumption of soluble carbohydrates and even the silage itself, resulting in delay in fermentation, less lactic acid production, high $\mathrm{pH}$ and at the same time reduce the quality of silage. In the post-opening period, the silo can change the stability of the material (JOBIM et al., 2007). The greater compression and consequent greater DM result in greater acceptability and digestibility of feed for animals (VELHO et al., 2007).

The clamped EM was higher $(\mathrm{P}<0.05)$ for the treatments containing corn(alone and Intercropping corn), these results are associated to the DM content, particle size at $2 \mathrm{~mm}$ and $\mathrm{pH}$ lower than others, resulting in a higher quality silage. The clamped SM of the grass-Tanzania with $32 \%$ of DM was similar to the intercropping and to the single Tanzania; however the single presented lower SM Tanzania compared to other treatments.

The single corn presented a difference $(\mathrm{P}<0.05)$ as the non-silage EM, being the Tanzania a determining factor on compression and density of the silage, DM, pH-independent and TP. The mixed silage showed lower PDM, while Tanzania 32\% DM, the biggest loss $(\mathrm{P}<0.01)$, corn and Tanzania presented intermediate values. Neumann et al. (2005) found no significant difference for PDM between different times of feed-out.

The Index of Dry Matter Recovery, or RDM, presents relationship with the non-silage DM content. The single grass-Tanzania presented the lowest result for bon-silage DM percentage $(22 \%)$ and showed $80.97 \%$ of RDM. The largest recovery of DM was presented by the intercropping and by Tanzania with high content of $\mathrm{DM}(\mathrm{P}<0.05)$, while corn presented intermediate values. These results reinforce the affirmative of the intercropping and older Tanzania have qualities superior to single cultures.

The loss for gases (LG) had a favorable outcome to Tanzania with highest content of DM (0.19\%) $(\mathrm{P}<0.05)$ when compared to single Tanzania. The single corn also presented great values with 
respect to the loss of gases $(0.27 \%)$; however, in the intercropping showed no difference among the other treatments. The low percentage of DM of young Tanzania may have contributed to this result. This is a feature that can compromise the quality of silage, because fodder with low levels of dry matter does not present adequate lactic fermentation, which favors the formation of butyric acid (CASTRO et al., 2006).

Single Tanzania and the one at $32 \%$ of DM showed higher levels of MM, with 10.26 and 9.86, respectively. The intercropping showed superiority in relation to corn $(\mathrm{P}<0$ 05), but was lower than the other treatments (Table 2). The largest concentrations of minerals for Tanzania may arise from the age of the plant, because plants in an initial development stage have more contents of minerals in their composition; another factor would be the genetic capacity of the plant to accumulate minerals.

Single corn culture presented above $(\mathrm{P}<0.01)$ for $\mathrm{OM}$ feature, $95.51 \%$. The intercropping gained $94.17 \%$, standing out $(\mathrm{P}<0.01)$ to single Tanzania crops. With these values, it is implied that the grass was responsible for the drop in production of organic matter when in the presence of corn, which presented the highest value. Pedó et al. (2009) found values next to corn at different heights, with an average of $95.87 \%$ organic matter with heights of $20,45,70$ and $95 \mathrm{~cm}$. Velho et al. (2007), assessing the OM of corn in different densities found that the higher the smaller the density OM, this result explains the results found in this work for the Intercropping corn $\mathrm{x}$ Tanzania.

To ADF, the higher result $(\mathrm{P}<0.01)$ went to the younger grass-Tanzania with $45.67 \%$. Tavares et al. (2009) found similar values for the witness treatment $(45.95 \%)$ when compared to silage with citrus pulp 5\% and pre-wilted Tanzania (42.63\% and $43.72 \%$, respectively). The reduction of the ADF by increasing the content of DM silage material is due to the best silage fermentation processes, which promotes the digestion of cellulose since the lignin present does not change.

There has been no difference to the content of Neutral Detergent Fiber (NDF). The levels of NDF vary according to the plant species, maturity, and plant growth conditions. The analysis of the levels of NDF of fodder because of this variation and their nutritional importance (WILSON, 1994).

The levels of CP for treatment with the presence of grass showed no difference between them, while the single corn had a content lower than to others $(10.4 \%)$, due to the phase of the vegetative stage of the plant at the time of harvest. The values found by Santos et al. (2008) for crude protein evaluating inoculants in Grass-Tanzania silage were $12 \%$ and $10 \%$, before the silage and to control treatment, respectively, since the fermentation microorganisms require nitrogen compounds for their development.

The CP values, the LIG, were superior $(\mathrm{P}<0.05)$ for treatments with the presence of Tanzania. The single young grass presented a $9.18 \%$ value, followed by the intercropping with the value of $8.36 \%$ and later Tanzania at $32 \%$ of DM with a value of $8.15 \%$ and corn presented a value of $5.39 \%$ of LIG. Possenti et al. (2005) found lower value for corn silage LIG when compared to silage of sorghum (3.7\% and 9.4\%, respectively). Leonel et al. (2009) found an average of $4.3 \%$ of lignin in single corn and $4.35 \%$ in mixed corn $\mathrm{x}$ brachiaria. It is known that the higher the lignin content, the greater the difficulty of digestion and lower utilization of food by the animal; thus, in this case, corn presented best quality and digestibility (Table 2).

There has been no difference to the acid detergent insoluble nitrogen (ADIN). A high content of NIDA is not desirable, because the nitrogen trapped in acid detergent fiber is not tapped by ruminal micro-organisms (VAN SOEST; MASON, 1991). However, the low levels of ADIN found in this work are insufficient to compromise the availability of nutrients for animal metabolism. 


\section{Conclusions}

The corn intercropping with grass-Tanzania provides a silage with a higher content of crude protein and lignin in comparison with corn exclusive silage, without harming the productivity of the crop.

The single-Tanzania silage features larger levels of ADF and crude protein, in addition to increased production of the dry matter silage corn.

Grass Tanzania must be harvested with a DM of $30 \%$ since it presented best values of $\mathrm{pH}$, higher rate of recovery of DM, less loss of gases, as well as increased dry matter production, than the Tanzania harvested with the same age of the corn.

\section{References}

ASSOCIATION OF OFFICIAL ANALYTICAL CHEMISTS - AOAC International. Official methods of analysis. 16. ed. 3. rev. Gaitherburg: Published by AOAC International, 1997. v. 2, cap. 32, p. 1-43.

ÁVILA, C. L. da S.; PINTO, J. C.; EVANGELISTA, A. R.; MORAIS, A. R. de; FIGUEIREDO, H. C. P.; TAVARES, V. B. Perfil de fermentação das silagens de capim-Tanzânia com aditivos -teores de nitrogênio amoniacal e pH. Ciências Agrotecnicas, Lavras, v. 27, n. 5, p. 1144-1151, 2003.

BHERING, S. B.; SANTOS, H. G. Mapa de solos do Estado do Paraná: legenda atualizada. Rio de Janeiro: EMBRAPA/IAPAR, 2008. $74 \mathrm{p}$.

CASTRO, F. G. F.; NUSSIO, L. G.; HADDAD, C. M.; CAMPOS, F. P.; COELHO, R. M.; MARI, L. J.; TOLEDO, P. A. Características de fermentação e composição químicobromatológica de silagens de capimtifton 85 confeccionadas com cinco teores de matéria seca. Revista Brasileira de Zootecnia, Viçosa, MG, v. 35, n. 1, p. 7-20, 2006.

CORRÊA, C. E. S.; SHAVER, R. D.; PEREIRA, M. N.; LAUER, J. G.; KOHN, K. Relationship between corn vitreousness and ruminal in situ starch degradability. Jornal of Dairy Science, Cambridge, v. 85, n. 11, p. 3008-3012, 2002.

EMPRESA BRASILEIRA DE PESQUISA AGROPECUÁRIA - EMBRAPA. Custos de forrageiras. Juiz de Fora: Embrapa Gado de Leite, 2005. Disponível em: <http://www.cnpgl.embrapa.br/nova/informacoes/ custos/custos2.php>. Acesso em: 2 abr. 2011.
INSTITUTO NACIONAL DE METEOROLOGIA INMET. Dados climáticos da estação automática de Dois Vizinhos. [S.1.; s.n], 2011. Disponível em: <http://www. inmet.gov.br>. Acesso em: 10 jul. 2011.

JOBIM, C. C.; NUSSIO, L. G.; REIS, R. A.; SCHMIDT, P. Avanços metodológicos na avaliação da qualidade da forragem conservada. Revista Brasileira de Zootecnia, Viçosa, MG, v. 36, p. 101-119, 2007. Suplemento Especial.

LEONEL, F. P.; PEREIRA, J. C.; COSTA, M. G.; MARCO JUNIOR, P. de; SILVA, C. J.; LARA, L. A. Consórcio capim-braquiária e milho: comportamento produtivo das culturas e características nutricionais e qualitativas das silagens. Revista Brasileira de Zootecnia, Viçosa, MG, v. 38, n. 1, p. 166-176, 2009.

LICITRA, G.; HERNANDEZ, T. M.; VAN SOEST, P. J. Standardization of procedures for nitrogen fractionation of ruminant feeds. Animal Feed Science and Technology, Madrid, v. 57, n. 4, p. 347-358, 1996.

LOURES, D. R. S.; NUSSIO, L. G.; PAZIANI, S. de F.; PEDROSO, A. de F.; MARI, L. J.; RIBEIRO, J. L.; ZOPOLLATTO, M.; SCHMIDT, P.; JUNQUEIRA, M. C.; PACKER, I. U.; CAMPOS, F. P. de. Composição bromatológica e produção de efluente de silagens de capim-tanzânia sob efeitos do emurchecimento, do tamanho de partícula e do uso de aditivos biológicos. Revista Brasileira de Zootecnia, Viçosa, MG, v. 34, n. 3, p. 726-735, 2005.

MAIA, M. C.; PINTO, J. C.; ANDRADE, I. F. de. Estabelecimento de pastagem de Capim-tanzânia usando milheto como cultura acompanhante. Revista Brasileira de Zootecnia, Viçosa, MG, v. 29, n. 5, p. 1312-1319, 2000.

NEUMANN, M.; RESTLE, J.; BRONDANI, I. L.; NÖRNBERG, J. L.; MELLO, R. de O.; SOUZA, A. N. M. de; PELLEGRINI, L. G. de. Efeito do tamanho da partícula e do tipo de silo sobre o valor nutritivo da silagem de sorgo (sorghum bicolor, 1. Moench). Revista Brasileira de Milho e Sorgo, Sete Lagoas, v. 4, n. 2, p. 224-242, 2005.

PEDÓ, L. F. B.; NÖRNBERG, J. L.; VELHO, J. P.; HENTZ, F.; HENN, J. D.; BARCELLOS, J. O. J.; VELHO, I. M. P. H.; MARX, F. R. Fracionamento dos carboidratos de silagens de milho safrinha colhidas em diferentes alturas de corte. Ciência Rural, Santa Maria, v. 39, n. 1, p. 181-194, 2009.

POSSENTI, R. A.; EVALDO JUNIOR, F.; BUENO, M. S.; BIANCHINI, D.; LEINZ, F. F.; RODRIGUES, C. F. Parâmetros bromatológicos e fermentativos das silagens de milho e girassol. Ciência Rural, Santa Maria, v. 35, n. 5, p. 1185-1189, 2005. 
SANTOS, E. M.; ZANINE, A. M.; FERREIRA, D. J.; OLIVEIRA, J. S.; PENTEADO, D. C. S.; PEREIRA, O. Inoculante ativado melhora a silagem de capim-tanzânia (Panicum maximum). Archivos Zootecnia, Cordoba, v. 57, n. 217, p. 35-42, 2008.

STATISTICAL ANALYSIS SYSTEM - SAS. System for Microsoft Windows: release 8.2. Cary: Statistical Analysis Systems, 2001. CD-ROM.

TAVARES, V. B.; PINTO, J. C.; EVANGELISTA, A. R.; FIGUEIREDO, H. C. P.; ÁVILA, C. L. da S.; LIMA, R. F. de. Efeitos da compactação, da inclusão de aditivo absorvente e do emurchecimento na composição bromatológica de silagens de capim-Tanzânia. Revista Brasileira de Zootecnia, Viçosa, MG, v. 38, n. 1, p. 4049, 2009.

VAN SOEST, P.J.; MASON, V.C. The influence of Maillard reaction upon the nutritive value of fibrous feeds. Animal Feed Science and Technology, Madrid, v .32, n. 1-3, 1991, p.45-53.
VELHO, J. P.; MÜHLBACH, P. R. F.; NÖRNBERG, J. L.; VELHO, I. M. P. H.; GENRO, T. C. M.; KESSLER, J. D. Composição bromatológica de silagens de milho produzidas com diferentes densidades de compactação. Revista Brasileira de Zootecnia, Viçosa, MG, v. 36, n. 5, p. 1532-1538, 2007.

WILSON, J. R. Cell wall characteristics in relation to forage digestion by ruminants: review. Journal Agriculture Science, Jordan, v. 122, n. 2, p. 173-182, 1994.

ZEOULA, L. M.; BELEZE, J. R. F.; CECATO, V.; JOBIM, C. C.; GERON, L. J. V.; PRADO, P. P.; FALCAO, A. J. S. Avaliação de cinco hídricos de milho (Zea mays, L.) em diferentes estágios de maturação. 4. Digestibilidade de matéria seca, matéria orgânica e fibra em detergente neutro da porção vegetativa e planta inteira. Revista Brasileira de Zootecnia, Viçosa, MG, v. 32, n. 3, p. 556-566, 2003. 